\title{
Factors that impact functional performance of elderly with low back pain
}

\author{
Fatores que impactam o desempenho \\ funcional de idosos com dor lombar
}

\author{
Flora Pereira Guerra, Rosângela Corrêa Dias, Leani Souza Máximo Pereira, \\ Luciana de Oliveira Assis, Marcella Guimarães Assis*
}

Universidade Federal de Minas Gerais (UFMG), Belo Horizonte, MG, Brazil

\begin{abstract}
Introduction: Low back pain is a common condition among older adults and an important cause of disability. Objective: To evaluate the relationship between functional performance of older adults with low back pain and the following variables: sociodemographic and clinical factors, self-perceived health and back pain beliefs. Methods: A cross-sectional study that used data from the Back Complaints in the Elders international consortium. Information about sociodemographic factors (sex, age, marital status, formal education), clinical factors (intensity and frequency of pain, comorbidities), self-perceived health, back pain beliefs and functional performance (measured by the disability component of the Late Life Function and Disability Instrument - LLFDI) were collected through self-report. 191 older adults above 60 years with a new episode of back complaints who did not have any cognitive disorder, visual or hearing impairment, or motor disabilities participated in the study. A bivariate analysis was conducted between each independent variable and each outcome. Associations with $\mathrm{p}<0.20$ were selected for the multiple linear regression analysis, which was carried out for each LLFDI domain. Results: The multiple regression coefficients of determination were significant despite the modest magnitude. The variables related to functional performance were
\end{abstract}

\footnotetext{
FPG: MS, e-mail: florapguerra@gmail.com RCD: PhD, e-mail: rcorreadias8@gmail.com LSMP: PhD, e-mail: leanismp.bh@terra.com.br LOA: PhD, e-mail: lucianaoassis@yahoo.com.br MGA: PhD, e-mail: mga@ufmg.br
} 
back beliefs, self-perceived health, formal education, pain frequency and marital status. Conclusion: These results may contribute to the expansion of health professionals' work in the therapeutic approach of low back pain, broadening its focus beyond clinical aspects in order to value beliefs of older adults and their self-perceived health.

Keywords: Elderly. Low Back Pain. Disability. Beliefs. Self-Perception.

\section{Resumo}

Introdução: A dor lombar é condição comum em idosos e importante causa de incapacidade nessa população. objetivo: Avaliar a relação das variáveis sóciodemográficas, clínicas, autopercepção de saúde e crenças como desempenho funcional de idosos com dor lombar. Métodos: Estudo transversal que utilizou dados do projeto multicêntrico Back Complaints in the Elders. A amostra foi de 191 idosos que relataram novo episódio de dor lombar em menos de 6 semanas e não apresentavam alterações cognitivas, deficiências visuais, auditivas e motoras graves. Através do auto relato, foram coletadas informações sobre características sóciodemográficas (sexo, idade, estado civil, escolaridade), clínicas (intensidade e frequência da dor, comorbidades), autopercepção de saúde, crenças em relação às consequências da dor lombar e desempenho funcional (componente de incapacidade do Late Life Function and Disability Instrument - LLFDI). Foi realizada a análise bivariada de cada variável independente com cada desfecho (6 diferentes escores fornecidos pelo componente de incapacidade do LLFDI) e aquelas que apresentaram significância $p<0,20$ entraram nos modelos de regressão múltipla para cada domínio do LLFDI. Resultados: Os coeficientes de determinação dos modelos multivariados foram significativos, apesar da modesta magnitude. As variáveis que se relacionaram com o desempenho funcional foram crenças, autopercepção de saúde, escolaridade, frequência da dor e estado civil. Conclusão: Esses resultados poderão contribuir para ampliação da atuação dos profissionais de saúde para além dos aspectos clínicos, valorizando as crenças dos idosos e sua autopercepção de saúde na abordagem terapêutica com foco na dor lombar.

Palavras-chave: Idosos. Dor Lombar. Incapacidade. Crença. Autopercepção.

\section{Introduction}

Musculoskeletal conditions in the elderly are a major cause of disabilities, especially low back pain which is considered a worldwide problem $(1,2)$.

Low back pain is defined as a pain between the lower edge of the 12th rib and the lower gluteal line, which is intense enough to limit usual activities or change daily routine $(3,4)$. It is considered a multifactorial condition relating to personal, biomechanical, psychosocial and environmental factors (5), and presents different stages of disability and chronicity $(4,6)$. It is prevalent in females and in the age group that ranges from 40 to 80 years old (6).

Low back pain is a common condition with an incidence rate of $25 \%$ in Brazilian older adults (7). Particular attention is drawn to the fact that functional performance is influenced by factors that go beyond the clinical characteristics of the individual.
Studies have shown that older adults with low back pain presented greater difficulty performing daily activities $(8,9)$. There is evidence that factors such as pain intensity and frequency $(10,11)$ and sex $(10)$ are associated with the functional performance of this population.

No studies were found correlating beliefs and selfperception about health with the functional performance of elderly with low back pain. However, two studies with individuals of various ages have shown that negative beliefs regarding low back pain are associated with a higher level of disability $(12,13)$. A study performed with older adults without specific health conditions verified that the greater the degree of dependence, the greater the chance of the elderly perceiving their health as poor (14).

There is no sufficient scientific evidence to correlate these variables with the functional performance of elderly with low back pain, which 
is fundamental to understand the real impact of this condition on their lives. Thus, the objective of this study was to evaluate the relationship of sociodemographic variables (sex, age, marital status, level of education), clinical variables (intensity and frequency of pain, comorbidities) and the variables of self-perception of health and beliefs with the functional performance of elderly with low back pain.

\section{Methods}

The present study uses a cross-sectional approach, and is part of the multicenter project Back Complaints in the Elders - BACE, developed by Australia, the Netherlands and Brazil, and has a published protocol (15). The BACE was approved by the Research Ethics Committee of UFMG under the opinion number: 0100.1.203.000-11. Participants signed the Free and Informed Consent Term.

\section{Sample}

The convenience sample consisted of data of 191 older adults in the age group between 60 and 94 years old, evaluated from the baseline of the BACE study between September 2011 and November 2012. Inclusion criteria for BACE were: age over 55 years old and presence of a new episode of low back pain (less than 6 weeks). The study excluded elderly individuals with cognitive alterations, or visual, hearing or motor disabilities. Recruitment was done by referral of health professionals who work in primary care, outpatient and hospital services.

\section{Instruments and Procedures}

The BACE project protocol included numerous assessment tools (15). The Mini Mental State Examination (MMSE) was first performed to identify cognitive alterations, considering the cutoff points proposed by Bertolucci (16). In the present study we used data from the sociodemographic, comorbidities and self-perception of health questionnaires, as well as the following evaluation protocols:

- Visual Analogue Scale (VAS): Often used to measure pain intensity by means of a numerical estimate ranging from 0 to 10 (17).
- Western Ontario and McMaster Universities Osteoarthritis Index (WOMAC): Quality of life questionnaire developed for individuals with knee and hip osteoarthritis. It evaluates three domains scored on a five-point Likert scale, namely: pain ( 5 items), rigidity ( 2 items) and physical function (17 items). This study used the first part of the questionnaire (pain domain). The average score for each domain ranges from 0 to 100 . The higher the score, the greater the effects (18). This test was validated for the Brazilian population (18), and was able to report the pain profile in individuals with and without low back pain, regardless of diagnosis (19).

- Back Beliefs Questionnaire (BBQ): Assesses beliefs regarding the potential negative consequences of low back pain. It consists of 14 items, of which 9 are valid for the final score and 5 are used as distractors. Each item is scored on a five-point Likert scale. The lower the score, the more negative the beliefs (20). The BBQ was translated and adapted for the Brazilian elderly population (21).

- Late Life Function and Disability Instrument (LLFDI): Evaluates the functional performance of the elderly. It is divided into two components: function and disability. The disability component was used in this study, which refers to performance in socially defined activities and evaluates the frequency of achievement and limitation in 16 daily activities, which includes basic, instrumental and advanced activities of daily living. The frequency dimension is divided into two role domains: social role (9 items) and personal role (7 items); and the limitation dimension in: instrumental role (12 items) and management role (4 items). The later division resulted in a group of activities involving more physical skills (instrumental role) and another involving more cognitive skills (management role). The instrument is applied with graphical assistance for answers.

LLFDI provides total scores for frequency and limitation, as well as for all four role domains. Each evaluated item receives a score that ranges from 1 to 5 . The sum of each item's score results in a final raw score that is transformed into a scale of 0 to 100 . 
The closer to 100, the higher the frequency of activities and the lower the limitation (22). This instrument was adapted for the Brazilian population and presented high levels of intra and inter-examiner reliability (23).

Statistical analysis

First, the statistical analysis had the goal of characterizing the sample. Then, the bivariate analysis of each independent variable was performed with each outcome. As the distribution of data was not considered normal, the KruskalWallis test was performed for nominal variables with more than two categories, the Mann-Whitney test for the nominal variables with two categories, and the Spearman correlation for the quantitative variables. Results with p-value lower than 0.20 identified variables that were later included in the multivariate regression models. A significance level of $5 \%$ was considered in all inferential analyses.

\section{Results}

The sample consisted of 191 older adults from the community aged 60 years old and over. Demographic, clinical, self-perceived health, beliefs, and functional performance characteristics are presented in Tables 1 and 2.

The bivariate analyzes that presented $\mathrm{p}<0.20$ indicated the independent variables entered into the multiple linear regression models for each LLFDI domain. These models used the enter method for variables selection. The results of bivariate analysis can be seen in Table 3 .

The regression models for each domain of the LLFDI test are shown in Table 4. The coefficients of determination of the multivariate models were significant, despite the limited magnitude. The models that presented the highest explanatory value $\left(R^{2}=0.20\right)$ were the instrumental role and limitation in performing the activities, in which the variables beliefs and self-perception of health remained significant. And also pain frequency, but only in the instrumental role. The results referring to the management role area did not reach statistical significance, thus they are not represented in the table.
Table 1 - Demographic, clinical and self-perceived health characteristics of participants $(n=191)$

\begin{tabular}{|c|c|}
\hline & $\mathrm{N}(\%)$ \\
\hline \multicolumn{2}{|l|}{ Sex } \\
\hline $\mathrm{F}$ & $167(87.4)$ \\
\hline M & $24(12.6)$ \\
\hline \multicolumn{2}{|l|}{ Age } \\
\hline 60 to 74 & $155(81.2)$ \\
\hline 75 and over & $36(18.8)$ \\
\hline \multicolumn{2}{|l|}{ Marital Status } \\
\hline Single & $37(19.4)$ \\
\hline Married / living with a partner & $83(43.4)$ \\
\hline Divorced & $20(10.5)$ \\
\hline Widower & $51(26.7)$ \\
\hline \multicolumn{2}{|l|}{ Level of Education } \\
\hline Illiterate & $8(4.2)$ \\
\hline Elementary School & $109(57.1)$ \\
\hline High School/Technical Course & $47(24.6)$ \\
\hline University Degree/Post-graduation & $27(14.1)$ \\
\hline \multicolumn{2}{|l|}{ Pain frequency } \\
\hline Not every day & $52(27.2)$ \\
\hline Every Day & $139(72.8)$ \\
\hline \multicolumn{2}{|l|}{ Self-perception of health } \\
\hline Excellent/Very Good & $27(14.1)$ \\
\hline Good & $106(55.5)$ \\
\hline Bad & $58(30.4)$ \\
\hline \multicolumn{2}{|l|}{ Comorbidities } \\
\hline None & $6(3.2)$ \\
\hline 1 up to 3 & $69(36.1)$ \\
\hline 4 or more & $116(60.7)$ \\
\hline
\end{tabular}

Table 2 - Characterization of the sample of clinical variables, beliefs and functional performance

\begin{tabular}{lcc}
\hline & N & $\begin{array}{c}\text { Average } \\
\text { (Standard deviation) }\end{array}$ \\
\hline WOMAC & 189 & $49.6(21.5)$ \\
VAS & 191 & $6.9(2.59)$ \\
Back Beliefs Questionnaire & 190 & $24.1(6.6)$ \\
LLFDI & & \\
Social role & 184 & $44.3(7.9)$ \\
Personal role & 189 & $56.6(11.3)$ \\
Instrumental role & 183 & $64.9(12.6)$ \\
Management role & 186 & $79.9(15.6)$ \\
Total frequency & 182 & $49.5(5.8)$ \\
Total limitation & 180 & $65.6(11.3)$ \\
\hline
\end{tabular}

Note: WOMAC - Western Ontario and McMaster Universities Arthritis Index; VAS - Visual Analogue Scale; LLFDI - Late Life Function and Disability Instrument. 
Table 3 - Bivariate analysis of factors associated with LLFDI dimensions and areas

\begin{tabular}{|c|c|c|c|c|c|c|}
\hline $\begin{array}{l}\text { LLFDI Components } \\
\text { and Domains }\end{array}$ & $\begin{array}{l}\text { Performance } \\
\text { frequency }\end{array}$ & $\begin{array}{l}\text { Performance } \\
\text { limitation }\end{array}$ & Social role & Personal role & $\begin{array}{l}\text { Instrumental } \\
\text { role }\end{array}$ & $\begin{array}{l}\text { Management } \\
\text { role }\end{array}$ \\
\hline \multicolumn{7}{|l|}{ Sex } \\
\hline $\mathrm{F}$ & $48.5(33.7-76.3)$ & $63.4(36.3-100)$ & $43.6(28.3-74.0)$ & $53.8(34.4-100)$ & $62.3(31.8-100)$ & $78.3(26.0-100)$ \\
\hline M & $49.1(38.1-58.0)$ & 65.7 (51.8-89.3) & $45.6(33.3-60.3)$ & $51.7(38.9-73.8)$ & $63.9(52.2-88.9)$ & $82.9(51.7-100)$ \\
\hline Value $p^{2}$ & 0.965 & $0.202^{*}$ & 0.407 & $0.078^{*}$ & $0.148^{*}$ & 0.634 \\
\hline \multicolumn{7}{|l|}{ Age } \\
\hline 60 up to 74 & $\begin{array}{c}48.8 \\
(33.7-70.6)\end{array}$ & $63.4(36.3-100)$ & $43.6(28.3-70.3)$ & $53.8(34.5-100)$ & $62.3(31.8-100)$ & $82.9(26.0-100)$ \\
\hline 75 or more & $47.6(39.4-76.3)$ & $62.0(49.2-100)$ & $41.1(31.8-74.0)$ & $51.7(31.8-74.0)$ & $62.3(49.4-100)$ & $74.5(41.0-100)$ \\
\hline Value $p^{2}$ & 0.119* & 0.650 & $0.110^{*}$ & 0.498 & 0.866 & 0.513 \\
\hline \multicolumn{7}{|l|}{ Marital Status } \\
\hline Single & $47.9(40.7-60.0)$ & $65.6(47.8-100)$ & $44.3(30.1-56.6)$ & $56.3(37.5-100)$ & $64.4(42.2-100)$ & 82. $9(41.0-100)$ \\
\hline $\begin{array}{l}\text { Married/Living } \\
\text { with a partner }\end{array}$ & $49.5(38.1-70.6)$ & $63.4(49.9-100)$ & $44.9(30.1-70.3)$ & $53.8(38.9-84.0)$ & $62.3(46.5-100)$ & $78.3(46.8-100)$ \\
\hline Divorced & $49.5(42.0-61.1)$ & $69.2(36.3-100)$ & $44.9(30.1-64.7)$ & $57.8(46.2-100)$ & $66.6(31.8-100)$ & $86.2(41.0-100)$ \\
\hline Widower & $\begin{array}{c}47.56 \\
(33.68-76.31)\end{array}$ & $\begin{array}{c}60.62 \\
(36.31-89.31)\end{array}$ & $\begin{array}{c}42.39 \\
(28.30-74.02)\end{array}$ & $\begin{array}{c}53.84 \\
(34.49-100)\end{array}$ & $\begin{array}{c}60.40 \\
(33.74-100)\end{array}$ & $\begin{array}{c}78.32 \\
(26.05-100)\end{array}$ \\
\hline Value $p^{1}$ & $0.170^{*}$ & $0.025^{\star}$ & $0.098^{*}$ & 0.483 & $0.026^{*}$ & $0.152^{*}$ \\
\hline
\end{tabular}

\section{Educational Level}

Illiterate

Elementary

School

High School/ Technical Course University Degree/PostGraduation

Value $p^{1}$

Pain frequency

Not every day

Every day

Value $\mathrm{p}^{2}$
Self-perception of

health

Excellent/Very

Good

Good

$\mathrm{Bad}$

Value $p^{1}$

\section{Comorbidities}

None

1 up to 3

4 or more

Value $p^{1}$

\section{WOMAC (rho)}

Value $p^{3}$
$45.1(33.7-50.1) \quad 59.0(49.2-75.6) \quad 37.3(28.3-51.8) \quad 47.0(34.5-56.3) \quad 58.6(44.5-74.1) \quad 69.2(63.9-100)$ $48.8(38.1-76.3) \quad 62.6(36.3-100) \quad 42.4(28.3-74.0) \quad 53.8(38.9-100) \quad 61.3(33.7-100) \quad 78.3(26.0-100)$ $48.2(42.0-61.1) \quad 64.1(52.5-100) \quad 43.6(31.8-64.7) \quad 53.8(37.5-84.0) \quad 64.4(46.5-100) \quad 82.9(51.7-100)$ $50.8(41.4-70.6) \quad 69.2(36.3-100) \quad 45.6(30.1-70.3) \quad 56.3(43.2-100) \quad 65.5(31.8-100) \quad 86.2(41.0-100)$ 0.036 * $0.088^{*}$

0.130 *

$0.061^{*}$

0.217

0.040 *

$48.5(33.7-70.6) \quad 66.4(51.2-100) \quad 42.4(28.3-70.3) \quad 55.1(34.5-100) \quad 67.8(46.5-100) \quad 80.6(41.0-100)$ $48.8(38.1-76.3) \quad 62.6(36.3-100) \quad 43.6(28.3-74.0) \quad 53.8(37.5-100) \quad 61.3(31.8-100) \quad 80.6(26.0-100)$

$\begin{array}{llllll}0.834 & \mathbf{0 . 0 5 1 *} & 0.933 & 0.582 & \mathbf{0 . 0 0 9} & 0.729\end{array}$


Table 3 - Bivariate analysis of factors associated with LLFDI dimensions and areas

\begin{tabular}{lcccccc}
\hline $\begin{array}{l}\text { LLFDI Components } \\
\text { and Domains }\end{array}$ & $\begin{array}{c}\text { Performance } \\
\text { frequency }\end{array}$ & $\begin{array}{c}\text { Performance } \\
\text { limitation }\end{array}$ & Social role & Personal role & $\begin{array}{c}\text { Instrumental } \\
\text { role }\end{array}$ & $\begin{array}{c}\text { Management } \\
\text { role }\end{array}$ \\
\hline VAS (rho) & -0.1 & -0.1 & -0.1 & 0.1 & -0.1 & -0.1 \\
Value p & 0.406 & $\mathbf{0 . 0 6 8 ^ { * }}$ & $\mathbf{0 . 1 0 8 ^ { * }}$ & $\mathbf{0 . 1 4 0 ^ { * }}$ & $\mathbf{0 . 0 5 1 ^ { * }}$ & 0.214 \\
\hline $\begin{array}{l}\text { Back Beliefs } \\
\text { Questionnaire (rho) }\end{array}$ & 0.2 & 0.3 & 0.2 & 0.2 & 0.3 & 0.2 \\
Value p & $\mathbf{. . 0 0 1}^{*}$ & $\mathbf{0 . 0 0 0 ^ { * }}$ & $\mathbf{0 . 0 1 7}^{*}$ & $\mathbf{0 . 0 0 1}^{*}$ & $\mathbf{0 . 0 0 0}^{*}$ & $\mathbf{0 . 0 0 8}^{*}$ \\
\hline
\end{tabular}

Note: ${ }^{1}$ Kruskal-Wallis Test. ${ }^{2}$ Mann-Whitney Test. ${ }^{3}$ Spearman Correlation. *value $p<0.20$ average (min - max)

Table 4 - Multiple linear regression models of factors associated with LLFDI dimensions and areas

\begin{tabular}{|c|c|c|c|c|c|}
\hline \multirow[t]{3}{*}{ LLFDI Components and Domains } & \multicolumn{5}{|c|}{ Standardized coefficients } \\
\hline & \multirow[t]{2}{*}{ Beta } & \multirow[t]{2}{*}{$T$} & \multirow[t]{2}{*}{$\mathbf{P}$} & \multicolumn{2}{|c|}{$\mathrm{Cl}(95 \%)$} \\
\hline & & & & Inferior & Superior \\
\hline \multicolumn{6}{|l|}{ Performance frequency $\left(R^{2}=0.157 ; p=0.002\right)$} \\
\hline Constant & & 17.011 & 0.000 & 39.455 & 49.815 \\
\hline Re-codified marital status single & -0.102 & -1.315 & 0.190 & -3.734 & 0.748 \\
\hline Re-codified marital status divorced & -0.127 & -1.636 & 0.104 & -5.286 & 0.495 \\
\hline Re-codified marital status widower & -0.072 & -0.909 & 0.365 & -2.981 & 1.101 \\
\hline Re-codified educational level illiterate & -0.214 & -2.927 & $0.004^{*}$ & -10.047 & -1.953 \\
\hline Re-codified educational level High School & -0.068 & -0.881 & 0.380 & -2.956 & 1.132 \\
\hline Re-codified educational level University Degree & -0.005 & -0.066 & 0.947 & -2.714 & 2.538 \\
\hline Re-codified self-perception excellent & 0.109 & 1.247 & 0.214 & -1.033 & 4.576 \\
\hline Re-codified self-perception good & 0.137 & 1.622 & 0.107 & -0.345 & 3.518 \\
\hline WOMAC & 0.050 & 0.644 & 0.521 & -0.028 & 0.055 \\
\hline Back Beliefs & 0.288 & 3.578 & $0.000^{*}$ & 0.114 & 0.396 \\
\hline Re-codified Age & -0.101 & -1.345 & 0.181 & -3.639 & 0.690 \\
\hline \multicolumn{6}{|l|}{ Performance limitation $\left(R^{2}=0.201 ; p=0.0001\right)$} \\
\hline Constant & & 8.231 & 0.0001 & 41.454 & 67.620 \\
\hline Back Beliefs & 0.219 & 2.688 & $0.008^{*}$ & 0.099 & 0.644 \\
\hline Re-codified sex & 0.095 & 1.221 & 0.224 & -1.903 & 8.078 \\
\hline Re-codified self-perception excellent & 0.159 & 1.841 & 0.067 & -0.364 & 10.397 \\
\hline Re-codified self-perception good & 0.170 & 2.034 & $0.044^{*}$ & 0.111 & 7.480 \\
\hline Re-codified marital status single & 0.052 & 0.651 & 0.516 & -2.979 & 5.912 \\
\hline Re-codified marital status divorced & 0.064 & 0.823 & 0.412 & -3.223 & 7.829 \\
\hline Re-codified marital status widower & -0.085 & -1.026 & 0.306 & -6.205 & 1.961 \\
\hline Re-codified educational level illiterate & -0.048 & -0.661 & 0.510 & -10.251 & 5.110 \\
\hline Re-codified educational level High School & 0.048 & 0.636 & 0.525 & -2.610 & 5.093 \\
\hline Re-codified educational level University Degree & 0.013 & 0.162 & 0.872 & -4.518 & 5.326 \\
\hline Re-codified Pain Frequency & -0.130 & -1.772 & 0.078 & -6.832 & 0.369 \\
\hline VAS & 0.006 & 0.073 & 0.942 & -0.684 & 0.737 \\
\hline WOMAC & -0.087 & -1.012 & 0.313 & -0.135 & 0.043 \\
\hline
\end{tabular}

(To be continued) 
Table 4 - Multiple linear regression models of factors associated with LLFDI dimensions and areas

(Conclusion)

\begin{tabular}{|c|c|c|c|c|c|}
\hline \multirow[t]{3}{*}{ LLFDI Components and Domains } & \multicolumn{5}{|c|}{ Standardized coefficients } \\
\hline & \multirow[t]{2}{*}{ Beta } & \multirow[t]{2}{*}{$T$} & \multirow[t]{2}{*}{$\mathbf{P}$} & \multicolumn{2}{|c|}{$\mathrm{Cl}(95 \%)$} \\
\hline & & & & Inferior & Superior \\
\hline \multicolumn{6}{|l|}{ Social role $\left(R^{2}=0.142 ; p=0.009\right)$} \\
\hline Constant & & 11.047 & 0.000 & 33.791 & 48.496 \\
\hline Re-codified age & -0.111 & -1.466 & 0.145 & -5.236 & 0.774 \\
\hline Re-codified marital status single & -0.151 & -1.899 & 0.059 & -6.196 & 0.120 \\
\hline Re-codified marital status divorced & -0.183 & -2.336 & $0.021^{*}$ & -8.748 & -0.734 \\
\hline Re-codified marital status widower & -0.121 & -1.491 & 0.138 & -5.006 & 0.698 \\
\hline Re-codified educational level illiterate & -0.172 & -2.344 & $0.020^{*}$ & -12.274 & -1.053 \\
\hline Re-codified educational level High School & -0.012 & -0.154 & 0.878 & -3.061 & 2.618 \\
\hline Re-codified educational level University Degree & -0.021 & -0.262 & 0.794 & -4.051 & 3.103 \\
\hline Re-codified self-perception excellent & 0.101 & 1.138 & 0.257 & -1.649 & 6.140 \\
\hline Re-codified self-perception good & 0.138 & 1.633 & 0.104 & -0.457 & 4.839 \\
\hline Back Beliefs & 0.221 & 2.719 & $0.007^{*}$ & 0.074 & 0.464 \\
\hline VAS & 0.039 & 0.470 & 0.639 & -0.394 & 0.639 \\
\hline WOMAC & -0.050 & -0.569 & 0.570 & -0.082 & 0.045 \\
\hline \multicolumn{6}{|l|}{ Personal role $\left(\mathrm{R}^{2}=0.114 ; \mathrm{p}=0.005\right)$} \\
\hline Constant & & 8.375 & 0.000 & 35.895 & 58.023 \\
\hline Re-codified sex & -0.075 & -1.029 & 0.305 & -7.477 & 2.352 \\
\hline Re-codified educational level illiterate & -0.154 & -2.158 & $0.032^{*}$ & -16.576 & -0.741 \\
\hline Re-codified educational level High School & -0.094 & -1.249 & 0.213 & -6.353 & 1.428 \\
\hline Re-codified educational level University Degree & 0.025 & 0.331 & 0.741 & -4.145 & 5.817 \\
\hline Re-codified self-perception excellent & 0.068 & 0.805 & 0.422 & -3.193 & 7.595 \\
\hline Re-codified self-perception good & 0.078 & 0.957 & 0.340 & -1.877 & 5.412 \\
\hline VAS & 0.086 & 1.160 & 0.247 & -0.262 & 1.010 \\
\hline Back Beliefs & 0.228 & 3.009 & $0.003^{*}$ & 0.135 & 0.650 \\
\hline \multicolumn{6}{|l|}{ Instrumental role $\left(R^{2}=0.203 ; p=0.0001\right)$} \\
\hline Constant & & 5.881 & 0.000 & 34.496 & 69.358 \\
\hline Re-codified sex & 0.118 & 1.540 & 0.125 & -1.220 & 9.884 \\
\hline Re-codified marital status single & 0.081 & 1.038 & 0.301 & -2.308 & 7.428 \\
\hline Re-codified marital status divorced & 0.080 & 1.050 & 0.295 & -2.856 & 9.346 \\
\hline Re-codified marital status widower & -0.077 & -0.960 & 0.339 & -6.637 & 2.295 \\
\hline Re-codified self-perception excellent & 0.158 & 1.850 & 0.066 & -0.377 & 11.629 \\
\hline Re-codified self-perception good & 0.189 & 2.338 & $0.021^{*}$ & 0.737 & 8.732 \\
\hline Re-codified Pain Frequency & -0.146 & -2.050 & $0.042^{*}$ & -8.129 & -0.153 \\
\hline VAS & 0.010 & 0.126 & 0.900 & -0.735 & 0.835 \\
\hline WOMAC & -0.091 & -1.062 & 0.290 & -0.153 & 0.046 \\
\hline Back Beliefs & 0.216 & 2.756 & $0.006^{*}$ & 0.117 & 0.705 \\
\hline Re-codified Comorbidities & -0.004 & -0.053 & 0.958 & -3.419 & 3.242 \\
\hline
\end{tabular}

Note: ${ }^{\star} p<0.05$ 


\section{Discussion}

The results showed an association between beliefs regarding the consequences of low back pain, selfperception of health, level of education, frequency of pain and marital status with the functional performance of elderly with low back pain.

Beliefs were related to the frequency and limitation dimensions and their respective role domains, with the exception of the management role. This result suggests that older adults with low back pain who have more negative beliefs regarding the consequences of this condition have worse functional performance, performing their activities with less frequency and greater limitation.

In another study, individuals of different ages with chronic low back pain had more organic beliefs related to low back pain than those who did not report pain. Organic belief is related to concepts of disease, damage and loss. The authors argue that this belief means that individuals do not perform exercises that would be beneficial because this recommendation is contrary to what they believe (24), which impacts on the functional performance of these individuals, and may explain the result presented above.

The older adults in this study who had more positive beliefs regarding low back pain presented fewer limitations, indicating that they have a better ability to cope with the adversities brought by the condition. This result can be reinforced by a study that evaluated the relation of beliefs of older adults about old-age and disability recovery. Those with positive beliefs were found to be $44 \%$ more likely to recover (25).

Another result found was the correlation of positive self-perception of health with a smaller limitation for accomplishing activities. Like LLFDI, self-perception of health has a multidimensional structure, and it is associated with factors of the individual's context such as socioeconomic situation, social support network, health conditions and the use of health services $(22,26)$, which explains the correlation found. Both enable individuals to consider several factors when assessing their health condition and limitations. Another possible explanation is the relation between health selfperception and coping capacity. In a study of older adults without a specific health condition, the assessment of the severity and relevance of a health problem was more associated with the possibility of facing it than with the problem itself (27). In this study, the elderly who classified their health as good or excellent presented fewer limitations, that is, they dealt better with the difficulties of lower back pain than those who considered they had poor health.

The results indicated that low levels of education are associated with a lower frequency of activities, regardless of whether they are related to the social or personal roles of the elderly. A review in 2001 summarizing scientific evidence of the relationship between educational level and low back pain corroborates this finding. The authors put forward some hypotheses to explain the result: individuals with low levels of education may live in environments with more difficulties, may be less able to adapt to adversities and have less access to information and guidance regarding their health condition (28).

Despite the fact that a 2009 study indicated educational level as the best predictor of beliefs regarding the consequences of low back pain, as individuals with higher education had more positive beliefs and better adapted to the consequences of low back pain (29), individuals in this study with lower levels of education did not report more limitations during the activities. It can be assumed that elderly with less education are less aware of their health condition and thus, do not report limitations (30).

The results showed that marital status is associated to the performance frequency of the activities that integrate the social role. In this study, widowers presented worse performance, a result corroborated by the study by Schoenborn (31), in which $69.9 \%$ of elderly widowers presented limitations in physical and social functioning. It should be emphasized that activities that integrate the social role involve a network of relationships of the individual, which may be diminished due to the loss of the spouse.

Pain frequency was related to the performance limitation in instrumental role activities, which require physical abilities (22). This finding was also demonstrated in a study conducted with community older adults in which the frequency of low back pain was associated with a perceived difficulty in performing activities that required physical effort, such as heavy housework (10).

The functional performance of the elderly in management role activities was not related to any of the investigated variables. This can be explained by the fact that low back pain affects more activities that require some physical effort and the activities listed in this role involve more cognitive abilities (22). 
In this study, the variables age and sex were not related to functional performance, contrary to what was presented in other research with the elderly $(10,32)$. Similar results were found in the study by Candotti et al. conducted with adults and elderly persons who had back pain (33).

There was also no significant relationship between performance in activities and intensity of pain and number of comorbidities. One possible explanation can be attributed to LLFDI's characteristic of asking about disabilities without a direct link to health. The instrument is based on a conceptual model that understands disability as the result of an interaction between the individual and the environment, which involves a broad set of social and cultural components. A study comparing the effects of using attributed and non-attributed health questions on the LLFDI limitation dimension score demonstrated that when there was no attribution to health individuals reported more disabilities, indicating the importance of other factors in addition to health in carrying out daily activities (34).

As a limitation to this study, it is worth highlighting the recruitment of health service participants, who may have selected elderly individuals with specific functional characteristics, as well as the predominance of the female sex in the sample, which reduced generalization of the results. In addition, the BACE project included a much broader spectrum of assessments than those used in the present investigation. Subsequent studies may make use of other collected information such as physical assessment data.

In conclusion, the functional performance of older adults with low back pain presented a relationship of modest magnitude with beliefs, self-perception of health, level of education, marital status and frequency of pain. The knowledge of these results can contribute to improving the evaluations and the interventions of health professionals, expanding its focus of action beyond the clinical aspects aimed at valuing the beliefs and self-perception of health of older adults.

\section{Acknowledgements}

To the BACE team, and to the professionals of the following institutions: Ambulatory Bias Fortes/
HC-UFMG (Ambulatório Bias Fortes/HC-UFMG), Jenny de Andrade Faria Institute/HC-UFMG (Instituto Jenny de Andrade Faria/HC-UFMG), Risoleta Tolentino Neves Hospital (Hospital Risoleta Tolentino Neves) and Social Welfare Hospital/ IPSEMG (Hospital da Previdência/IPSEMG).

Financial Support: National Council for Scientific and Technological Development (CNPq - Conselho Nacional de Desenvolvimento Cientifico e Tecnológico). Process N. 471264/2010-5; Minas Gerais Research Support Foundation (FAPEMIG - Fundação de Amparo à Pesquisa de Minas Gerais). Process APQ-0156513; Coordination of Support to Higher Education Personnel (CAPES - Coordenadoria de Apoio ao Pessoal de Ensino Superior).

\section{References}

1. Woolf AD, Pfleger B. Burden of major musculoskeletal conditions. Bull World Health Organ. 2003;81(9):646-56.

2. Hoy D, Bain C, Williams G, March L, Brooks P, Blyth F, et al. A systematic review of the global prevalence of low back pain. Arthritis Rheum. 2012;64(6):2028-37.

3. Dionne CE, Dunn KM, Croft PR, Nachemson AL, Buchbinder $\mathrm{R}$, Walker $\mathrm{BF}$, et al. A consensus approach toward the standardization of back pain definitions for use in prevalence studies. Spine. 2008;33(1):95-103.

4. van Tulder M, Becker A, Bekkering T, Breen A, del Real MT, Hutchinson A, et al. Chapter 3. European guidelines for the management of acute nonspecific low back pain in primary care. Eur Spine J. 2006;15(Suppl 2):169-91.

5. Gilkey DP, Keefe TJ, Peel JL, Kassab OM, Kennedy CA. Risk factors associated with back pain: a crosssectional study of 963 college students. J Manipulative Physiol Ther. 2010;33(2):88-95.

6. Balagué F, Mannion AF, Pellisé F, Cedraschi C. Clinical update: low back pain. Lancet. 2007;369(9563):726-8.

7. Leopoldino AAO, Diz JBM, Martins VT, Henschke N, Pereira LSM, Dias RC, et al. Prevalência de lombalgia na população idosa brasileira: revisão sistemática com metanálise. Rev Bras Reumatol. 2016;56(3):258-69. 
8. Hicks GE, Gaines JM, Shardell M, Simonsick EM. Associations of back and leg pain with health status and functional capacity of older adults: findings from the retirement community back pain study. Arthritis Rheum (Arthritis Care \& Research). 2008;59(9):1306-13.

9. Ledoux E, Dubois JD, Descarreaux M. Physical and psychosocial predictors of functional trunk capacity in older adults with and without low back pain. J Manipulative Physiol Ther. 2012;35(5):338-45.

10. Weiner DK, Haggerty CL, Kritchevsky SB, Harris T, Simonsick EM, Nevitt M, et al. How does low back pain impact physical function in independent, wellfunctioning older adults? Evidence from the health $\mathrm{ABC}$ cohort and implication for the future. Pain Med. 2003;4(4):311-20.

11. Weiner DK, Rudy TE, Kim YS, Golla S. Do medical factors predict disability in older adults with persistent low back pain? Pain. 2004;112(1-2):214-20.

12. Elfering A, Mannion AF, Jacobshagen N, Tamcan $\mathrm{O}$, Müller U. Beliefs about back pain predict the recovery rate over 52 consecutive weeks. Scand J Work Environ Health. 2009;35(6):437-45.

13. Smith AJ, O'Sullivan PB, Beales D, Straker L. Back pain beliefs are related to the impact of low back pain in 17-year-olds. Phys Ther. 2012;92(10):1258-67.

14. Alves LC, Rodrigues RN. Determinantes da autopercepção de saúde entre idosos do Município de São Paulo, Brasil. Rev Panam Salud Publica. 2005;17(5-6):333-41.

15. Scheele J, Luijsterburg PAJ, Ferreira ML, Maher CG, Pereira L, Peul WC, et al. Back Complaints in the Elders (BACE); design of cohort studies in primary care: an international consortium. BMC Musculoskeletal Disorders. 2011;12(193):1-9.

16. Bertolucci PHF, Brucki SMD, Campacci SR, Juliano Y. O mini-exame do estado mental em uma população geral: impacto da escolaridade. Arq Neuropsiquiatr. 1994;52(1):1-7.

17. Andrade FA, Pereira, LV, Sousa FAEF. Mensuração da dor no idoso: uma revisão. Rev Latino-Am Enfermagem. 2006;14(2):271-6.
18. Fernandes MI. Tradução e validação do questionário de qualidade de vida específico para osteoartrose WOMAC (Western Ontario McMaster Universities) para a língua portuguesa [master's thesis]. São Paulo: Universidade Federal de São Paulo; 2003.

19. Wolfe F. Determinants of WOMAC function, pain and stiffness score: evidence for the role of low back pain, symptom counts, fatigue and depression in osteoarthritis, rheumatoid arthritis and fibromyalgia. Rheumatology. 1999;38(4):355-61.

20. Symonds TL, Burton AK, Tillotson KM, Main CJ. Do attitudes and beliefs influence work loss due to low back trouble? Occup Med. 1996;46(1):25-32.

21. Teixeira LF. Atitudes e crenças sobre dor lombar em idosos da comunidade: dados do estudo BACE [dissertation]. Belo Horizonte: Universidade Federal de Minas Gerais; 2015.

22. Jette AM, Haley SM, Coster WJ, Kooyoomjian JT, Levenson S, Heeren T, et al. Late life function and disability instrument: I. Development and evaluation of the disability component. J Gerontol A Biol Sci Med Sci. 2002;57(4):M209-16.

23. Cardoso AP, Mancini MC, Guerra FP, Pereira LSM, Assis MG. Confiabilidade do Late-Life Function and Disability Instrument (LLFDI) versão português do Brasil em amostra de idosos com alta escolaridade. Cad Ter Ocup. 2015;23(2):237-50.

24. Sloan TJ, Gupta R, Zhang W, Walsh DA. Beliefs about the causes and consequences of pain in patients with chronic inflammatory or noninflammatory low back pain and in pain-free individuals. Spine. 2008;33(9):966-72.

25. Levy BR, Slade MD, Murphy TE, Gill TM. Association between positive age stereotypes and recovery from disability in older persons. JAMA. 2012;308(19):1972-3.

26. Lima-Costa MF, Firmo JOA, Uchôa E. A estrutura da auto-avaliação da saúde entre idosos: projeto Bambuí. Rev Saúde Pública. 2004;38(6):827-34.

27. Uchôa E. Contribuições da antropologia para uma abordagem das questões relativas à saúde do idoso. Cad. Saúde Pública. 2003;19(3):849-53. 
28. Dionne CE, Von Korff M, Koepsell TD, Deyo RA, Barlow WE, Checkoway H. Formal education and back pain: a review. J Epidemiol Community Health. 2001;55(7):455-68.

29. Bowey-Morris J, Davis S, Purcell-Jones G, Watson PJ. Beliefs about back pain Results of a population survey of working age adults. Clin J Pain. 2011;27(3):214-24.

30. Hacihasanoglu R, Yildirim A, Karakurt P. Loneliness in elderly individuals, level of dependence in activities of daily living (ADL) and influential factors. Arch Gerontol Geriatr. 2012;54(1):61-6.

31. Schoenborn CA. Marital status and health: United States, 1999-2002. Adv Data. 2004;(351):1-32.

32. Ribeiro PCC, Neri AL, Cupertino APFB, Yassuda MS. Variabilidade no envelhecimento ativo segundo gênero, idade e saúde. Psicol Estud. 2009;14(3):501-9.
33. Candotti CT, Noll M, Marchetti BV, Rosa BN, Medeiros MGS, Vieira A, et al. Prevalence of back pain, functional disability and spinal postural changes. Fisioter Mov. 2015;28(4):711-22.

34. Dubuc N, Haley SM, Kooyoomjian JT, Jette AM. Assessing disability in older adults: the effects of asking questions with and without health attribution. J Rehabil Med. 2004;36(5):226-31.

Received in $03 / 31 / 2016$

Recebido em 31/03/2016

Approved in 04/10/2017

Aprovado em 10/04/2017 